\title{
PELAKSANAAN TRANSAKSI AKAD JUAL BELI DALAM KOMPILASI HUKUM EKONOMI SYARIAH (KHES) KECAMATAN TAMPAN PEKANBARU
}

\author{
${ }^{1}$ Muhammad Azani, ${ }^{2}$ Hasan basri, ${ }^{3}$ Dewi Nurjannah Nasution \\ ${ }^{1,2,3}$ Fakultas Hukum Universitas Lancnag Kuning \\ Email: ${ }^{1}$ mhd.azani@unilak.ac.id, ${ }^{2}$ Hasan.basri@unilak.ac.id, ${ }^{3}$ dewinurjannah48@gmail.com
}

\section{Info Artikel:}

\begin{tabular}{l|l|l} 
Diterima: 20 Agustus 2020 & | Disetujui: 05 Agustus $2021 \quad$ Dipublikasikan: 12 Agustus 2021
\end{tabular}

\begin{abstract}
Abstrak
Akad jual beli adalah suatu pertukaran (exchanging) antara suatu komoditas dengan uang atau antara komoditas dan komoditas lain.Dimana tulisan ini memaparkan tentang apa itu jual beli, Rukun dan syarat akad jual beli dalam Kompilasi hukum ekonomi Islam yang didalamnya ada beberapa ketentuan dalam pelaksanaan jual beli. Kemudian ada hak yang berkaitan dengan harga dan barang setelah akad jual beli yang di dalamnnya mengatur hak yang dilakukan setelah akad jual beli lalu ada jual beli yang dilakukan oleh orang pailit dan sakit keras yang mengatur ketentuan jual beli bagi orang yang sedang pailit dan sakit keras, lalu memuat juga informasi singkat tentang konsep yang ada dalam jual beli dan di akhir makalah memuat kesimpulan atau penutup tentang rumusan masalah dari makalah ini.
\end{abstract}

Kunci: akad, jual beli, dan KHES

\section{IMPLEMENTATION OF PURCHASE CONTRACT TRANSACTIONS IN SHARIA ECONOMIC LAW (KHES) COMPILATION TAMPAN DISTRICT PEKANBARU \\ Abstract}

Sale and purchase agreement is an exchange (exchanging) between a commodity with money or between commodities and other commodities. Where this paper describes what is buying and selling, Pillars and terms of sale and purchase agreement in the Compilation of Islamic economic law in which there are several provisions in selling buy. Then there are rights relating to prices and goods after the sale and purchase agreement which regulates the rights carried out after the sale and purchase agreement and then there is a sale and purchase carried out by a bankrupt and seriously ill person who governs the terms of sale and purchase for people who are bankrupt and seriously ill, then includes also brief information about the concepts that exist in the sale and purchase and at the end of the paper contains conclusions or conclusions about the formulation of the problem of this paper.

Keywords: contract, sale and purchase, and KHES

Jurnal Gagasan Hukum Vol. 03 | No.01 | 2021 | 


\section{A. PENDAHULUAN}

Manusia merupakan makhluk sosial, yakni tidak hidup sendiri dan selalu membutuhkan orang lain dalam memenuhi segala kebutuhan sehari - hari, termasuk dalam hal jual beli , baik dalam urusan diri sendiri maupun untuk kemaslahatan umum. Namun seringkali terjadi dalam melakukan jual beli,sering terjadi kecurangan yang dapat merugikan masyarakat.

Untuk melakukan jual beli, pasti melaksanakan suatu transaksi. Si penjual menjual barangnya, dan si pembeli membeli barangnya si penjual dengan transaksi/menukarkan barang tersebut dengan transaksi yang telah keduanya sepakati.

Dalam pelaksanaan akad,dunia bisnis memiliki peran penting hal ini dikarenakan adanya kegiatan jual beli kedepannya akan bergantung seberapa baik akad yang dibuat untuk mengatur hak dan kewajiban kedua belah pihak yang melaksanakan akad.

Akad dalam pelaksanaannya sebagai suatu perjanjian yang mengikat hubungan antara penjual dan pembeli. Jual beli atau perdagangan dalam istilah fiqih disebut dengan al-bai' yang menurut etimologi berarti menjual atau mengganti. Wahbah Al-Zuhaily dalam artian bahasa "menukar sesuatu dengan sesuatu yang lain". Kata albai' dalam Arab terkadang digunakan untuk pengertian lawannya, yaitu kata alsyira' (beli). Al-bai' adalah jual, tetapi sekaligus juga berarti beli. Secara terminologi terdapat beberapa definisi jual beli yang dikemukakan para ulama' fiqh sekalipun substansi yang bertujuan masingmasing artian sama. Menurut Sayyid sabiq, jual beli adalah pertukaran harta dengan harta atas dasar saling merelakan atau memindahkan milik dengna ganti yang didapat dibenarkan.

Menurut Hanafiyah yang yang dikutip oleh Wahbahal-Zuhaily, jual beli adalah saling tukar harta dengan harta melalui cara tertentu atau tukar-menukar sesuatu yang diinginkan dengan yang sepadan melalui cara tertentu yang bermanfaat. ${ }^{1}$

Menurut Ibnu Qudamah (salah seorang ulama Malikiyah) yang dikutip oleh Wahbahal-Zuhaily, jual beli adalah saling menukar harta dengan harta dalam bentuk pemindahan milik dan kepemilikan.

Sedangkan menurut ulama' Hanafiyah pengertian jual beli (al-bai') adalah tukarmenukar harta benda atau sesuatu yang diinginkan dengan sesuatu yang sepadan melalui cara tertentu yang bermanfaat. Adapula menurut ulama' Malikiyah, Syafi'iyah, dan Hanabilah, bahwa jual beli (al-bai') adalah tukar-menukar harta dengan harta pula dalam bentuk pemindahan milik dan kepemilikan.

Berdasarkan pada Kompilasi Hukum Ekonomi Syariah bab IV Pasal 57 bahwa

\footnotetext{
${ }^{1}$ Jurnal hukum dan syariah volume 7 no. 1
} 2016 
pihak-pihak yang terkait pelaksanaan perjanjian jual beli terdiri dari penjual, pembeli dan pihak lain yang yang terlibat dalam perjanjian jual beli tersebut.

Dari beberapa pengertian di atas dapat dipahami bahwa inti dari pengertian jual beli adalah suatu perjanjian tukar-menukar benda atau barang yang mempunyai nilai secara sukarela antara kedua belah pihak, yang satu menerima benda-benda dan pihak lain menerimanya sesuai dengan perjanjian atau ketentuan yang dibenarkan syara' dan disepakati. Untuk lebih mengetahui tentang akad jual beli dapat kita lihat pada rumusan masalah.

Rumusan masalah

1) Bagaimanakah rukun dan syarat akad jual beli dalam Kompilasi Hukum Ekonomi Islam?

2) Bagaimanakah hak yang berkaitan dengan harga dan barang setelah akad jual beli?

3) Bagaimanakah akad jual beli yang dilakukan oleh orang yang pailit atau dinyatakan pailit?

\section{B. METODE PENELITIAN}

Jenis penelitian ini merupakan jenis penelitian lapangan, yaitu penelitian ini di lakukan dalam kehidupan masyarakat. Adapun lokasinya yang berasa di kecamatan Sidomulyo Barat, Pekanbaru, Riau

Pengumpulan Data merupakan langkah yang penting dalam penelitian.
Tanpa adanya pengumpulan data bearti penelitian tidak dapat dilakukan. Namun setelah dilakukan pengumpulan data penelitian bukan menjamin menghasilkan kesimpulan yang memuaskan karena kualitas penelitian tidakhanya ditentukan oleh keberadaan data, tetapi juga oleh cara pengambilan data. Pengumpulan data dalam penelitian ini yaitu penelitian lapangan. Tanpa mengetahui pengumpulan data, maka penelitian tidak dapat memenuhi standard data yang ditetapkan.

Teknik Pengumpulan Data dalam penelitian ini dilakukan dengan menggunakan teknik wawancara. Wawancara diartikan sebagai cara yang digunakan untuk mendapatkan informasi dari responden dengan cara Tanya jawab langsung ke tokoh masyarakat. Sebelum melakukan wawancara segala keperluan dipersiapkan, seperti daftar pertanyaan, buku catatan untuk mencatat jawaban responden, dan lainnya.

Data - data yang telah didapat akan dikelompokkan berdasarkan prioritas

\section{HASIL DAN PEMBAHASAN}

1. Rukun dan Syarat Akad Jual Beli dalam Kompilasi Hukum Ekonomi Syariah (KHES)

Berdasarkan Pasal 62 KHES bagian kedua tentang kesepakatan penjual dan 
pembeli yang berbunyi "Penjual dan pembeli wajib menyepakati nilai objek jual beli”. Rukun dan syarat akad jual beli dalam KHES berasal dari bahasa Arab yakni, al-'Aqd.

Akad adalah perjanjian (yang tercatat) atau kontrak. Dalam Ensiklopedia Hukum Islam, al-'aqd memiliki arti perikatan, perjanjian, dan pemufakatan (al-ittifaq). Kaidah Fikih menyebutkan bahwa akad merupakan sebagai pertalian ijab (pernyataaan melakukan ikatan ) dan kabul (pernyataan penerimaan ikatan) sesuai dengan hukum Islam, sehingga terjadi perpindahan kepemilikan dari satu pihak ke pihak yang lain. ${ }^{2}$

Menurut istilah, akad adalah hubungan atau keterkaitan antara ijab dan qabul atas dikursus dan dibenarkan oleh syara' dan memiliki implikasi hukum tertentu. Menurut Hasbi Ash-Shiddieqy bahwa akad adalah perikatan antara ijâb dengan qabul yang dibenarkan oleh syara'.

Pelaksanaan akad dalam transaksi perdagangan diharuskan adanya kerelaan kedua belah pihak, atau yang diistilahkan 'antarâdhin minkum'. Walaupun kerelaan tersebut merupakan sesuatu yang tersembunyi di lubuk hati, tetapi indikator dan tanda-tandanya dapat terlihat. Ijâb dan qabûl dalam adat kebiasaan di masyarakat sebagai serah terima

\footnotetext{
${ }^{2}$ M. Ali hasan, Berbagai macam transaksi dalam Islam (jakarta:raja grafindo persada, 2004)
}

merupakan bentuk-bentuk yang digunakan hukum untuk menunjukkan kerelaan. Akad atau kontrak berkaitan dengan barang/harta benda (mâl), hak pemanfaatan harta benda, dan transfer kepemilikan atas barang/hak atas pemanfaatan harta benda dari para pihak.

Berdasarkan Pasal 20 ayat 2 KHES menyebutkan bahwa bai' merupakan jual beli antara benda dengan benda, atau pertukaran antara benda dengan uang. Definisi dalam pasal di atas, dirujuk dari pengertian jual beli dalam terminologi fikih, yakni jual beli diartikan dengan menjual, mengganti, dan menukar sesuatu dengan sesuatu yang lain. ${ }^{3}$

Jual beli adalah perbuatan tukar menukar benda atau barang yang mempunyai nilai dengan pemindahan kepemilikan benda tersebut dengan aturan hukum dan syara'. Kata Benda di atas dapat diartikan dengan barang dan uang. Sifat benda tersebut harus dapat dinilai yakni benda-benda yang berharga dan dapat dibenarkan penggunaannya menurut syara ${ }^{, 4}$

Baik benda tersebut bergerak (dipindahkan), tetap (tidak dapat dipindahkan), dapat dibagi-bagi, tidak dapat

\footnotetext{
${ }^{3}$ Menurut Hanafiah,jual beli (al-bai') yaitu tukar menukar harta benda atau sesuatu yang diinginkan dengan sesuatu yang sepadan melalui cara tertentu yang bermanfaat. Sedangkan menurut Malikiyah, Syafi'iyah, dan Hanabilah,jual beli (albai') yaitu tukar menukar harta dengan harta pula dalam bentuk pemindahan milik dan kepemilikan.

4 Abdul Ghofur hukum perjanjian islam indonesia, hlm . 41-44
} 
dibagi-bagi, dan lain sebagainya.

Penggunaan harta tersebut diperbolehkan sepanjang tidak dilarang oleh syara'.

Rukun jual beli yang diatur dalam KHES adalah sebagai berikut:

a. Berakal

Dalam pelaksanaan rukun jual beli ialah berakal, karena orang berakal dapat membedakan yang baik dan buruk untuk dirinya atau pun orang lain. Anak yang belum cakap hukum, tidak sah melakukan transaksi jual beli, kecuali mendapat ratifikasi dari orang tua atau wali.

b. Akad itu adalah orang yang berbeda.

Dalam artian bahwa, seseorang tidak dapat bertindak dalam waktu yang bersamaan sebagai penjual, sekaligus pembeli. ${ }^{5}$ Akad jual beli dilakukan oleh dua orang atau lebih,tidak bisa hanya satu orang, ada yang disebut penjual dan pembeli.

c. Dengan kehendak sendiri (bukan dipaksa)

Paksaan yang dapat merugikan para pihak, baik dari penjual atau pembeli,tidak sah melakukan akad jual beli. Dalam KHES terjadinya akad jual

5 Al-quran surat an-Nisa' ayat 29 artinya: "Hai orang-orang yang beriman, janganlah kamu saling memakan harta sesamamu dengan jalan yang batil, kecuali dengan jalan perniagaan (jual beli) yang berlaku dengan suka sama suka diantara kamu"

beli itu harus dengan kehendak sendiri, tidak ada paksaan oleh orang lain.

Dalam ketentuan Al-quran surat anNisa' ayat 29 terdapat kata "suka sama suka" bahwa yang menjadi dasar jual beli haruslah kehendak sendiri, tidak dalam tekanan dan tipu daya.

d. Baligh atau dewasa

Anak yang belum kecakapan hukum tidak sah melakukan transaksi jual beli. Dikatakan kecakapan hukum KHES usia dewasa bagi laki - laki berumur 19 tahun dan bagi perempuan 16 tahun.

Adapun syarat benda yang menjadi objek akad sebagai berikut :

a. Suci

Suci adalah syarat yang harus ada pada benda tersebut untuk melakukan transaksi. Mazhab Hanafi dan Mazhab Zhahiri mengecualikan barang yang ada manfaatnya, hal itu dinilai halal untuk dijual. ${ }^{6}$

b. Ada manfaatnya

Tidak boleh menjual sesuatu yang tidak ada manfaatnya. Dalam Al-quran, sebagaimana di dalam surat al-Isra' ayat 27 yang berbunyi; "Sesungguhnya pemborospemboros itu saudara setan”. Jual beli seperti gajah, burung merak,

\footnotetext{
${ }^{6}$ Al-quran, surat al-Isra' ayat 27
} 
burung beo dan lainnya yang bisa dimanfaatkan untuk kebutuhan.

c. Barang itu dapat diserahkan

Penjual yang barangnya tidak dapat di serahkan secara langsung kepada pembeli, dikatakan tidak sah transaksi jual beli, misalnya ikan di dalam laut, barang rampasan yang masih ada ditangan yang merampasnya, dan barang yang dijaminkan, karena mengandung tipu daya,

d. Milik sendiri

Barang jual beli haruslah milik pihak penjual. Tidak dapat dikatakan sah,barang yang bukan milik penjual. Penjual yang bukan pemilik barang bisa melakukan akad, tetapi sebelum melakukan akad harus ada persetujuan pemilik barang.

e. Diketahui

Barang dan harga pada transaksi jual beli yang tidak diketahui, jual beli tersebut tidak sah, karena mengandung unsur penipuan, kecuali barang dan harga telah di ketahui.

f. Barang yang diakadkan ada di tangan

Barang yang belum di tangan pembeli tidak sah. Karena bisa terjadi kerusakan sebelum di tangan pembeli.

\section{Hak Yang Berkaitan Dengan Harga Dan Barang Setelah Akad Jual Beli}

Akad jual beli menjadi hubungan timbal balik antara penjual dan pembeli. Penjual mendapatkan uang pembayaran dan pembeli mendapatkan barang yang dibutuhkan. Penjual dapat memanfaatkan uang hasil pembayaran, dan sebaliknya pembeli dapat memanfaatkan barang pembeliannya.

Dengan demikian, diharapkan mendapat tindak sesuai dengan kewenangan tanpa melanggar aturan dan hukum syari'at.

Berikut beberapa ketentuan penting yang harus diindahkan oleh pembeli:

a. Pemindahan Kepemilikan

Akad jual beli yang telah berlangsung, pembeli bisa memindahkan kepemilikan barang. Dengan demikian, barang yang telah djual secara sah dan menjadi milik pembeli, sehingga penjual tidak lagi berhak menggunakannya. Ketentuan ini berlaku jika pembeli telah melakukan pembayaran atau hanya membayar sebagiannya dari sepakatan.

b. Manfaat dan kerugian barang

Segala manfaat barang dan kerugian yang telah terjadi akad penjualan, maka menjadi hak pembeli. Ketentuan ini sepenuhnya berlaku saat barang yang menjadi 
objek akad jual beli telah diserahkan kepada pembeli.

Hukum ini berlaku pada penjualan barang selain buahbuahan atau biji-bijian yang masih di atas pohonnya. Hukum ini berlaku pihak penjual telah memberikan menyerahkan kepada pembeli untuk memanen buah atau biji-bijian yang telah dibeli. Pengecualian ini berdasarkan sabda Rasulullah Shallallahu 'alaihi wasallam:

"Bila engkau membeli buah-buahan dari saudaramu, lalu ditimpa bencana, maka tidak halal bagimu sedikit pun dari pembayarannya. Atas dasar apa engkau memakan uang pembayarannya tanpa alasan yang dibenarkan?",

Ketentuan hukum ini berlaku jika pembeli belum sepenuhnya menerima barang yang dibelinya, walaupun penjual telah memberikan kesempatan kepadanya untuk memanennya.

Gagal panen yang menimpa, terjadi di luar kemampuannya sebagai manusia biasa:

c. Menjual Kembali (Resale)

Pihak pembeli berhak menggunakan barang atau menjualnya kembali, terhadap barang yang telah dibelinya.

\footnotetext{
${ }^{7}$ Riwayat Muslim hadits no. 1554
}

Ada tiga yang harus dihindari pada penjualan kembali barang yang telah beli oleh pembeli sebagai berikut :

a. Jangan Menjual Kembali Kepada Penjual.

Menjualan kembali kepada penjual pertama tentu menimbulkan tanda tanya besar, mengapa dan apa untungnya? Karena itu, hukum Islam mewaspadai praktik-praktik semacam ini.

1) Menjual kembali kepada penjual pertama maka ada kemungkinan sebagai berikut:

Membeli dengan pembayaran terhutang dan menjual kembali dengan pembayaran tunai. Kemungkinan ini yang terjadi,praktik ini merupakan terjadinya praktik riba. Biasanya penjual pertama menjual dengan harga mahal, kemudian membeli kembali dengan harga yang murah karena pembeliannya dengan berupa tunai.

2) Bahwa penjualan kembali dengan pembayaran tunai atau terhutang dengan harga yang sama atau lebih mahal dari harga penjualan sebelumnya, maka tidak masalah. Yang kekhawatiran adanya praktik riba tidak terwujud, sehingga 
tidak ada alasan untuk melarang penjualan ini. ${ }^{8}$

\section{b. Menjual Kembali Di Tempat Penjual Pertama.}

Barang yang dibeli pada dasarnya telah menjadi milik pembeli, sehingga idealnya pembeli bertanggung jawab penuh atas segala yang terjadi padanya. Keuntungan atau kerugian telah mejadi tanggung jawab pembeli. Untuk memperkecil resiko terhadap barang, pembeli menjualnya kembali, walaupun barang tersebut asih berada ditempat penjual pertama. Dalam hal ini dapat terlihat adanya praktik riba

Biasanya, yang sudi membeli dari penjual kedua sedangkan ia-calon pembelitelah sampai di tempat penjual pertama adalah orang yang tidak mampu melakukan pembayaran tunai. Dengan demikian, sejatinya penjual kedua hanya sebatas menghutangi sejumlah uang kepada pembeli kedua, dan kemudian penjual kedua mendapatkan keuntungan dari piutang tersebut. ${ }^{9}$

c. Menjual Sebelum Menerima Barang.

Diantara hal yang harus perhatikan, sebelum menjual kembali barang pembelian adalah keberadaan barang tersebut. Bila

\footnotetext{
${ }^{8}$ Berdasarkan sabda Rasulullah Shallallahu 'alaihi wasallam berikut:"Barang siapa melakukan dua akad penjualan dalam satu transaksi jual beli, maka ia harus menggunakan harga yang termurah, bila tidak maka ia telah terjerumus dalam praktik riba." [Riwayat Abu Dawud hadits no. 3463]

9 . Bukhari hadits no. 2006 dan Muslim hadits no. 1531
}

barang yang dibeli belum terima, karena dalam proses pengiriman atau bahkan sedang dalam proses produksi, maka pembeli tidak dibenarkan untuk menjualnya kembali sampai barang itu benar-benar tiba di tangan pembeli. Yang demi menutup praktik-praktik riba. Praktik riba yang berupa uang melahirkan uang tanpa ada pergerakan barang atau jasa.

d. Ketentuan tidak dapat membatalkan penjualan atau pembelian

Di antara akad jual beli adalah kedua pihak tidak dapat membatalkan akad yang terjalin sebelum ada ke sepakatan untuk membatalkannya. Hal ini berlaku saat tidak menemukan kecacatan atau tindak kecurangan.

e. Bebas menentukan harga jual

Diantara konsekuensi atas kepemilikan pembeli terhadap suatu barang yang telah dibeli, maka berhak menentukan berapa pun harga jualnya. Bebas untuk memasang nilai keuntungan yang dikehendakinya.

Abu al-Rahman dalam karyanya mengatakan bahwa rukun jual beli itu berjumlah enam, yaitu sighat, akid, makudalaih. Jumlah enam dipahami olehnya, karena setiap satu rukun itu pada dasarnya dua. Misalnya sighat, di dalam sighat (kata) ini ada dua yaitu ijab dan qabul. Demikian juga dengan akid (orang yang akad) di dalamnya terdiri dari penjual dan pembeli. Juga mak'udalaih (barang 
yang diperjual belikan), di dalamnya ada dua, yaitu memberi dan menerima.

Abdu al-Rahman mengatakan salah satu rukun jual beli itu harus sighat. Sighat yang dimaksud dengan Abdu al-Rahman bisa dengan kata-kata atau dengan perbuatan (tindakan). Sesorang mengambil barang yang dijual, terus memberikan uang pada penjual, dan tidak berkata sedikitpun, maka disebut dengan sighat. Abu Hanifah (Mazhab Hanafi) mengutarakan , yang memiliki faham yang sama. Namun Abdu al-Rahman juga tidak menafsirkan pendapat yang silang, seperti yang diutarakan oleh Imam Syafi'i, yang mengatakan bahwa sighat harus dilakukan dengan bahasa atau tercatat yang dapat dipahami oleh kedua belah pihak, dan bagi seseorang yang tidak bisa berbicara, maka cukupdengan isyarat yang dapat dimengerti oleh kedua belah pihak.

Abdu al-Rahman menjelaskan akid (orang yang melakukan akad), orang yang akan melakukan jual beli harus memenuhi syarat. Di antara syarat pada akid, adalah mumayiz(orang yang bisa membedakan yang baik dan buruk sekalipun anak anak).

Menurut Abdu al-Rahman tidak sah melakukan akad,bagi anak yang belum mumayiz dan orang dalam pengampuan, kecuali di bawah pengawasan orang tua atau wali. Dalam hal ini Abdu al-Rahman bersebrangan dengan pendapat Imam
Syafi'i, dan Imam Ahmad. Namun sunggupun demikian Abdu al-Rahman mengutarakan pendapat ulama yang bersebrangan. yakni Imam Ahmad yang mengatakan bahwa anak- anak(al-shabiy) ,mumayiz, atau belum sah melakukan akad jual beli, sedangkan menurut Imam Syafi'I, bahwa tidak dianggap sah al-shabiy melakukan akad jual beli.

Abdu al-Rahman berpendapat barang yang diperjual belikan (makud alih). syarat barang yang diperjual belikan harus suci. Untuk itu barang yang najis tidak sah diperjual belikan. ${ }^{10}$ Bependapat harus disucikan terlebih dahulu, selain itu, barang yang dijual belikan harus diketahui bentuk atau harga.

Didalam ilmu sosial tindakan dapat dikelompokan sebagai Tindakan biasa yaitu, tindakan yang dilakukan tanpa melibatkan orang lain dan kedua tindakan social yaitu tindakan sosial, tindakan yang dilakukan dan melibatkan orang lain atau social.

\section{Akad Jual Beli Yang Dilakukan Oleh Orang Yang Pailit Atau Dinyatakan Pailit}

a. Jual beli terhadap orang yang terhalang pailit dan boros (bodoh atau pemborosan)

\footnotetext{
${ }^{10}$ (al-Nisa ayat 29) islaminomic vol. v.no.2
} ,agustus 2016 hlm. 82 
Jual beli orang bodoh yang suka menghamburkan hartanya, menurut pendapat ulama Malikiyah, Hanafiyah dan pendapat paling Shahih di kalangan Hanabilah, harus ditangguhkan. ${ }^{11}$

Menurut ulama Syafi'iyah, jual beli tersebut tidak sah dikarenakan tidak ada ahli dan ucapannya dapat tidak dipegang. Berdasarkan ketetapan hukum, menurut ulama Malikiyah dan Hanafiyah menyatakan bahwa seseorang dinyatakan jatuh pailit hanya yang telah ditetapkan oleh hakim,jika belum ada putusan dari hakim, maka segala tindakan hukumnya dinyatakan tetap sah. Yang berhutang atau bangkrut telah dinyatakan oleh hakim jatuh pailit, maka hakim berhak bertindak hukum terhadap sisa hartanya, apabila perbuatannya membawa mudharat kepada orang yang memberinya hutang, dan hakim juga berhak menjadikannya dibawah pengampuan, serta berhak menahannya. Hakim bisa menjual sisa harta orang yang telah jatuh pailit dan membagikannya kepada para pemberi hutang selama dalam tahanan.

b. Jual beli terhadap orang yang sakit

Menurut jumhur selain Malikiyah, jual beli terhadap orang sakit parah, hanya dibolehkan sepertiga dari hartanya (tirkah), dan bila ingin lebih

\footnotetext{
${ }^{11}$ Pendapat Shahih di kalangan Hanabilah
}

dari sepertiga, jual beli tersebut ditangguhkan kepada izin ahli warisnya. Menurut Ulama Malikiyah, sepertiga dari hartanya hanya dibolehkan pada harta yang tidak bergerak seperti rumah, tanah dll.

Didalam masyarakat seringkali terjadi permasalahan jual beli yang tidak berdasarkan Kompilasi Hukum Ekonomi Syariah (KHES).

Ada beberapa permasalahan yang terjadi di msyarakat misalnya,kelurahan Sidomulyo Barat yang berlokasi kecamatan Tampan, kota Pekanbaru yang sebagai berikut : Adanya jual beli borongan dengan akad di awal Jual beli merupakan salah satu bentuk antara manusia dalam bidang pencarian yang di syariatkan dalam islam. Adanya jual beli, manusia dapat memenuhi kebutuhan sehari - hari serta manusia tidak dapat hidup sendiri. Dengan adanya perkembangan yang semakin pesat sekarang ini memunculkan bisnis dagang yang mengikuti perkembangan zaman pula, yang di antaranya jual beli buah papaya dan buah pisang yang digunakan oleh masyarakat berada di kelurahan Sidomulyo Barat tersebut. Dalam prakteknya jual beli yang terjadi dimasyarakat Sidomulyo Barat menggunakan sistem borongan,dimana 
pembeli merasa dirugikan pada kualitas buah yang dibeli,pembeli tidak dapat melihat kondisi buah yang dibeli, dikarenakan buah telah dikemas.

"Banyak masyarakat sekitar yang berdagang buah - buahan yang di rugikan pada saat membeli buah borongan, misalnya, buah papaya, jeruk dan semangka. Pembeli buah borongan tidak bisa melihat langsung buah borongan tersebut, dikarenakan buang sampai dalam keadaan didalam peti, buah yang busuk terdapat di bawah dan dia atasnya buah buah yang bagus, penjual borongan mencampurkan dengan buah yang segar agar tidak terlihat." Ujar tokoh masyarakat.

Orang yang melakukan akad jual beli harus ada pembeli dan penjualnya, dalam praktek jual beli di Sidomulyo Barat ini tidak ada masalah karena ada pelaku pembeli dan penjual tetap ada. Pada syarat terhadap barang yang dijual belikan harus ada manfaatnya dalam hal ini buah yang dijual dimasyarakat Sidomulyo Barat merupakan barang yang bermanfaat karena berupa makanan,sebagaimana masyarakat dapat memenuhi vitamin bagi tubuh.

Shighat akad adalah bentuk uangkapan dari ijab dan qabul. Di zaman modern,melakukan ijab dan Kabul tidak lagi di ucapkan tetapi dilakukan dengan sikap mengambil barang dan membayar uang oleh pembeli,seta menerima uang dan menyerahkan barang oleh penjual tampa ucapan apapun.

Hukum islam mensyariatkan aturan- aturan yang berkaitan dengan antara induvidu untuk kebutuhan hidupnya. Jual beli yang dilakukan di kelurahan Sidomulyo Barat bertentangan dengan syara'. Pada dasarnya syari'at Islam dari awal mulanya mengakui adat dan tradisi dalam masyarakat selagi tidak bertentangan dengan Al Quran dan Hadist.

Pedagang yang melakukan jual beli borongan tersebut telah menjadi kebiasaaan masyarakat. Oleh karena itu perlu adanya solusi bagi masyarakat agar tetap bisa bertransaksi tetapi tidak keluar dari hukum islam.

c. Adanya jual beli dalam objek jual curian Maksud dari objek jual curian adalah menjual barang yang bukan miliknya tampa izin dari pemiliknya. Dalam syarat barang yang menjadi akad jual beli yaitu milik sendiri, suatu barang yang akan dijadikan akad jual beli harus milik sendiri, tidak sah jika barang bukan milik sendiri, misyalnya kendaraan bermotor. Dikatakan sah jual beli itu, setelah pemiliknya mengizinkan. Berdasarkan KHES, pasal 76 huruf (d) barang yang dijualbelikan 
harus halal, huruf (e) barang yang dijualbelikan harus diketahui oleh pembeli, huruf (f) kekhususan barang yang dijualbelikan harus diketahui, huruf (g) penunjukkan dianggap memenuhi syarat kekhususan barang yang dijualbelikan jika barang itu ada di tempat jual beli, huruf (h) sifat barang yang dapat diketahui secara langsung oleh pembeli tidak memerlukan penjelasan lebih lanjut.

"Ada beberapa masyarakat yang mempunyai kendaraan bermotornya tidak memiliki Surat Tanda Nomor Kendaraan, setelah di telusuri mereka mendapatkannya oleh orang yang tidak dikenal,masyarakat tetep membelinya karena kendaraan yang tidak memiliki surat itu lebuh murah di banding yang bersurat" ujar tokoh masyarakat.

Jual beli yang memenuhi atau sesuai dengan rukun dan syarat sahnya akad jual beli, lebih banyak manfaatnya dari pada mudharatnya dan tidak bertentangan dengan hukum islam.

d. Harga barang di sesuaikan dengan harga barang yang saat ini.

Maksudnya, objeknya sama tetapi harga di samakan dengan harga barang yang baru. Penjual menaikkan harga dan menyamakan dengan barang yang baru masuk. Harga bisa dikatakan sebagai penentu utama pembelian, pada umumnya harga ditetapkan melalui negosiasi antara penjual dan pembeli. Menyebabkan kesulitan bagi orang lain untuk memproleh kebutuhannya.
"Pedagang - pedagang yang ada disini menjual barang dagangannya harga sama dengan barang baru masuk, barang baru tersebut harganya berbeda dengan harga barang stok lama, itu menyebabkan masyarakat kesulitan saat membeli barang yang disamakan dengan harga barang lama." ujar tokoh masyarakat

Hal ini juga menimbulkan penjualan yang akan berdampak kemacetan sendi - sendi prekonomian. Sehingga orang - orang kurang mampu akan sangat sulit membeli kebutuhannya.

Pedagang sebaiknya jangan menyamakan harga stok baru dengan harga stok lama,itu hanya menyebabkan pembeli tidak akan bisa memenuhi kebutuhannya yang seharusnya terpenuhi pembeli.

\section{PENUTUP}

Rukun dan syarat akad jual beli dalam kompilasi hukum ekonomi islam. Para Ulama fikih sepakat menyatakan bahwa orang yang melakukan akad jual beli menurut subjeknya harus memenuhi syarat antara lain: syarat benda atau barang yang menjadi obyek akad. Objek jual beli di sini dapat diartikan sebagai benda yang menjadi sebab terjadinya perjanjian jual beli.

Hak yang berkaitan dengan harga dan barang setalah akad jual beli. Akad jual beli telah menjadi sarana petukaran barang antara penjual dan pembeli. Penjual mendapatkan uang pembayaran dan pembeli mendapatkan barang. Akan tetapi, 
ada beberapa poin penting yang seyoginya Anda ketahui sebelum Anda memanfaatkan barang pembelian Anda.

Akad jual beli yang dilakukan oleh orang yang pailit atau dinyatakan pailit dan orang yang sedang sakit keras. Jual Beli Terhadap orang yang terhalang pailit \& boros (bodoh,atau pemboros)Maksud terhalang di sini adalah terhalang karena kebodohan, bangkrut. Jual beli terhadap orang yang sakit Menurut jumhur selain Malikiyah, jual beli orang sakit parah yang sudah mendekati mati hanya dibolehkan sepertiga dari hartanya (tirkah), dan bila ingin lebih dari sepertiga, jual beli tersebut ditangguhkan kepada izin ahli warisnya. Menurut Ulama Malikiyah, sepertiga dari hartanya hanya dibolehkan pada harta yang tidak bergerak seperti rumah, tanah dll.

Didalam masyarakat seringkali terjadi permasalahan jual beli yang tidak berdasarkan Kompilasi Hukum Ekonomi Syariah (KHES). Ada beberapa permasalahan yang terjadi dikelurahan Sidomulyo Barat yang berlokasi kecamatan Tampan, kota Pekanbaru yang sebagai berikut: adanya jual beli borongan dengan akad di awal. Jual beli merupakan salah satu bentuk antara manusia dalam bidang pencarian yang di syariatkan dalam islam. Adanya jual beli, manusia dapat memenuhi kebutuhan sehari-hari, manusia tidak dapat hidup sendiri. Dengan adanya perkembangan yang semakin pesat sekarang ini memunculkan bisnis dagang yang mengikuti perkembangan zaman pula, yang di antaranya jual beli buah papaya dan buah pisang yang digunakan oleh masyarakat berada di kelurahan Sidomulyo Barat tersebut. Dalam prakteknya jual beli yang terjadi dimasyarakat Sidomulyo Barat menggunakan sistem borongan,dimana pembeli merasa dirugikan pada kualitas buah yang dibeli,pembeli tidak dapat melihat kondisi buah yang dibeli, dikarenakan buah telah dikemas. Orang yang melakukan akad jual beli harus ada pembeli dan penjualnya, dalam praktek jual beli di Sidomulyo Barat ini tidak ada masalah karena ada pelaku pembeli dan penjual tetap ada. Pada syarat terhadap barang yang dijual belikan harus ada manfaatnya dalam hal ini buah yang dijual dimasyarakat Sidomulyo Barat merupakan barang yang bermanfaat karena berupa makanan,sebagaimana masyarakat dapat memenuhi vitamin bagi tubuh. 


\section{DAFTAR PUSTAKA}

Anwar, Syamsul. Studi Hukum Islam

Kontemporer, Yogyakarta: UIN

Sunan Kalijaga Press, 2007.

Dimyati, Ahmad. Ekonomi Etis: Paradigma

Baru Ekonomi Islam, Riba: Jurnal

Ekonomi Islam, Vol I, Nomor 2, 2007.

Hadiyanto, M. Fajar. Praktek Riba dan Kesenjangan Sosial, Jurnal Ekonomi Islam, Vol II, Nomor 2, Desember 2008.

Hulam, Taufiqul. Jaminan dalam Transaksi Akad Mudarabah Pada Perbankan Syariah, Mimbar Hukum, Vol. 22, No. 3, Oktober 2010, 520-533.

Marabona Munthe, Peran Pemerintah dalam Mendukung Penerapan Ekonomi Kerakyatan Berbasis Syariah, Jurnal Ekonomi Islam alAmwal: $\quad$ Ekonomi Islam Membangun Ekonomi Dunia, Volum I, Nomor 1, 2012.
Misanam, Munrokhim, dkk. Ekonomi Islam, Jakarta : PT. Raja Grafindo Persada, 2008.

Muhammad. Kebijakan Fiskal dan Moneter dalam Ekonomi Islami, Yogyakarta: Salemba Empat, 2002.

Tarsidin, Bagi Hasil: Konsep dan Analisis, Jakarta: Lembaga Penerbit Fakultas Ekonomi, 2010.

Wiratmanto,Penanganan pembiayaan bermasalah dalam pelaksanaan akad dengan prinsip murabahah di Bank Muamalat Indonesia Cabang Yogyakarta, Jurnal Media Hukum, Vol. 16, No. I, hlm. 101-114.

Kompilasi Hukum Ekonomi Syariah (KHES) Bab II tentang Akad.

Peraturan Mahkamah Agung (M.A.) Republik Indonesia Nomor 02 Tahun 2008 tentang Kompilasi Hukum Ekonomi Syariah (KHES). 